\title{
Effects of Theophylline on the Neonatal Immune Response
}

\author{
J. E. BALEY, ${ }^{(23)}$ O. RUUSKANEN, K. MILLER, AND W. B. PITTARD III \\ Department of Pediatrics, Case Western Reserve University, Rainbow Babies and Childrens Hospital, \\ Cleveland, Ohio, USA
}

\begin{abstract}
Summary
Theophylline has recently been shown to affect lymphocyte reactivity. In view of its widespread use in newborn intensive care units, the effects on both lymphocyte proliferation and immunoglobulin production at varied throphylline concentrations were measured. In 12 adults and 10 term infants lymphocyte proliferation, as assessed by a whole blood micromethod, was significantly decreased in vitro at $7.5 \mu \mathrm{g} / \mathrm{ml}$. Immunoglobulin production in adults was decreased, by both a plaque forming cell assay and a radioimmunoassay in vitro at $12.5 \mu \mathrm{g} / \mathrm{ml}$. Ten premature infants on theophylline, mean serum level $7.8 \pm 0.4 \mu \mathrm{g} / \mathrm{ml}$, followed for 3$5 \mathrm{wk}$, showed a slight increase in lymphocyte proliferative responses to pokeweed mitogen. These data demonstrate no in vivo suppression of lymphocyte proliferation in theophylline-treated neonates at low theophylline levels.
\end{abstract}

\section{Speculation}

Low dose theophylline therapy in premature infants does not interfere with mitogen-induced lymphocyte proliferation. Further studies of the effects of theophylline on immunoregulatory function in neonates may demonstrate adverse effects.

After reports of a significant reduction in apnea among theophylline-treated premature infants (21), this drug has become one of the more widely used medications in neonatal intensive care units. Theophylline has several well known toxic side effects, including tachycardia, gastritis, hypertension, hyperthermia, diuresis, and central nervous system irritability, with occasional reports of severe toxicity leading to seizures and death (19). More recently, and less well known, theophylline has clearly been shown to affect immune reactivity, both in vitro $(8,9,18)$ and in vivo $(6$, $13)$. Should this occur in the premature infant, it could be associated with a decreased resistance to infection. This is of particular concern because the premature infant's immune system is undergoing marked maturational changes and drug-induced alterations could become permanent.

To determine if theophylline affects immune responses, we measured in vitro immunoglobulin production in adult lymphocyte cultures, and in vitro adult and neonatal mitogen-induced lymphocyte proliferation at varying theophylline concentrations. On the basis of these data, we then prospectively monitored the lymphocyte proliferative responses among 10 theophylline-treated premature infants.

\section{MATERIALS AND METHODS}

Assay for lymphocyte proliferation. Lymphocyte proliferation was assessed using a whole blood micromethod (16). Blood samples from young adults were collected by antecubital venipuncture. Blood was also collected from 3-day-old, healthy, term infants, as well as premature infants on theophylline therapy, via heel stick skin puncture or umbilical artery catheter. Sterile, heparinized, $250 \mu$ l Natelson glass pipettes were used for the skin puncture blood samples. Blood was then diluted 1:11 with RPMI-1640 (GIBCO, Grand Island, NY), containing penicillin 250 units $/ \mathrm{ml}$, streptomycin $100 \mu \mathrm{g} / \mathrm{ml}$, and Hepes Buffer (Microbiological Associates, Bethesda, MD) $2.5 \mathrm{ml} / 100 \mathrm{ml}$. After dilution, one hundred and ninety $\mu$ l of diluted blood was pipetted into microtiter plate wells (No. 3040, Falcon Plastics), already containing 10 $\mu l$ of pokeweed mitogen (PWM, Grand Island Biological Co.) and varying theophylline concentrations. This stock PWM, diluted 1:5 with sterile normal saline, induced optimal proliferation in preliminary studies with adult and neonatal lymphocytes. All cultures were made in triplicate. The plates were incubated at $37^{\circ} \mathrm{C}$ in humidified $5 \% \mathrm{CO}_{2}$ for $72 \mathrm{~h}$, after which $1 \mu \mathrm{Ci}$ of $\left[^{3} \mathrm{H}\right]$-methylthymidine (specific activity $24 \mathrm{Ci} / \mathrm{mmole}$ ) was pipetted into each well. After an additional $24 \mathrm{~h}$ incubation, the cultures were harvested with a multiple microharvester, using washes of both water and saline. The radioactivity in the filter disc was measured in a Searle Isocap 300 liquid scintillation counter and responses were expressed as mean cpm of the triplicates.

Assays for immunoglobulin production. Heparinized adult venous blood mononuclear cells were separated by Ficoll-Hypaque (Pharmacia Fine Chemicals) gradients, according to the method of Boyum (2). The lymphocytes were cultured and the indirect protein A plaque forming cell assay performed, as described by Fauci et al. (7). Five $\times 10^{5}$ mononuclear cells in $1 \mathrm{ml}$ of RPMI1640 containing penicillin, streptomycin, and $10 \%$ heat-inactivated fetal calf serum (GIBCO) were incubated in $12 \times 75 \mathrm{~mm}$ round bottom plastic tubes. Cultures were activated with PWM (10 $\mu \mathrm{l} /$ $\mathrm{ml}$ of a 1:5 dilution with sterile normal saline) and then incubated at $37^{\circ} \mathrm{C} 5 \% \mathrm{CO}_{2}$ in air at $100 \%$ humidity for 6 days. After this, the cells were harvested, washed, and resuspended in cold RPMI1640. One tenth $\mathrm{ml}$ cell suspension mixed with $0.85 \mathrm{ml}$ agarose (Accurate Chemicals, Hicksville, NY) and $0.60 \mathrm{ml} 15 \%$ solution protein A-coated sheep red blood cells were poured onto an agarose precoated petri dish (Falcon No. 1007) and incubated at $37^{\circ} \mathrm{C}$ for $2 \mathrm{~h}$. One $\mathrm{ml}$ of the IgG fraction (1:100 in RPMI-1640) of rabbit antihuman polyvalent immunoglobulin (Cappel Labs, Cochranville, PA) was then layered on the plate and incubated again for $2 \mathrm{~h}$, after which the antisera was removed and $1 \mathrm{ml}$ of guinea pig complement ( $1: 40$ in veronal buffered saline) added. After a further $1 \mathrm{~h}$ incubation, the complement was removed and PFC read at $\times 4$ magnification, and expressed as PFC per $10^{6}$ cultured cells.

Patient population. The first 12 premature infants placed on theophylline, from whose parents informed consent was obtained, were studied. All infants were begun on theophylline for apneic and bradycardic episodes. No infant with positive blood and/or cerebral spinal fluid cultures before onset of therapy was accepted into the study. Mean birth weights and gestational ages were 1164 g (range $740-1440 \mathrm{~g}$ ) and $30 \mathrm{wk}$ (range $26-35 \mathrm{wk}$ ), respectively. Seven infants were clearly appropriate weight for gestational age (AGA) and one small weight for gestational age (SGA). Two 
infants had 10th percentile weights for their gestational age. Immune responses on each infant were followed for 3-5 wk. Two infants died of multiple complications of prematurity.

Loading doses of $5 \mathrm{mg} / \mathrm{kg}$ theophylline were used, followed by 1-2 $\mathrm{mg} / \mathrm{kg} /$ day. Initial therapy was intravenous. Many infants were later given oral therapy. Serum theophylline levels were measured in each blood specimen studied using high pressure liquid chromatography.

Written informed consent was obtained for all individuals studied.

Statistical analysis. All data was analyzed with the paired $t$ test. Significance was considered achieved at $P<0.05$.

\section{RESULTS}

Effects of in vitro theophylline on immune responses in adults and neonates. Adult and neonatal lymphocyte proliferative responses to pokeweed mitogen (PWM) were measured, utilizing the whole blood micromethod. In both adults and healthy term neonates, lymphocyte proliferation was significantly decreased at theophylline levels of $7.5 \mu \mathrm{g} / \mathrm{ml}(P<0.05)$, with further decreases in proliferation at higher theophylline levels (Table 1). In the adult, responses fell from $13,985 \pm 2067 \mathrm{cpm}$ (mean \pm S.E.) in cultures with no theophylline to $8112 \pm 1971 \mathrm{cpm}$ in cultures with theophylline levels of $15.0 \mu \mathrm{g} / \mathrm{ml}$. Similarly, in the neonate, control cultures generated a mean of $18,310 \pm 2219 \mathrm{cpm}$, whereas cultures with $15.0 \mu \mathrm{g} / \mathrm{ml}$ theophylline had 13,030 $\pm 2009 \mathrm{cpm}$.

Immunoglobulin production was assessed (in adult lymphocyte cultures) with two different methods. The mean release of immunoglobulin as determined by double antibody radioimmunoassay (22), in PWM-activated adult lymphocyte cultures with theophyl-

Table 1. Adult and neonatal lymphocyte proliferative responses to pokeweed mitogen

\begin{tabular}{ccc}
$\begin{array}{c}\text { Theophylline } \\
(\mu \mathrm{g} / \mathrm{ml})\end{array}$ & $\begin{array}{c}\text { Adult } \\
\text { cpm } \pm \text { S.E. }\end{array}$ & $\begin{array}{c}\text { Neonatal } \\
\text { cpm } \pm \text { S.E. }\end{array}$ \\
\hline$n$ & 12 & 10 \\
0 & $13985 \pm 2067$ & $18310 \pm 2219$ \\
2.5 & $12810 \pm 2251^{1}$ & $18645 \pm 2691$ \\
7.5 & $10695 \pm 2018^{3}$ & $16825 \pm 2221^{1}$ \\
12.5 & $9982 \pm 2112^{2}$ & $16791 \pm 2201^{2}$ \\
15.0 & $8112 \pm 1971^{2}$ & $13030 \pm 2009^{3}$ \\
\hline
\end{tabular}

\footnotetext{
${ }^{3} P<0.05$

${ }^{2} P<0.01$

${ }^{3} P<0.001$
}

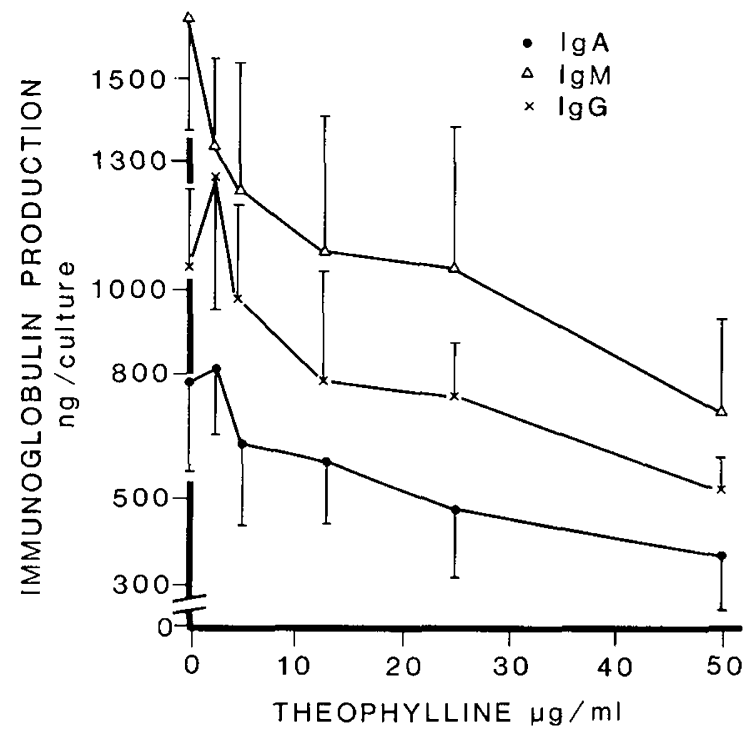

Fig. 1. Theophylline effect on adult immunoglobulin production.
Table 2. Adult plaque forming cell response to pokeweed mitogen

\begin{tabular}{cc}
\hline $\begin{array}{c}\text { Theophylline } \\
(\mu \mathrm{g} / \mathrm{ml})\end{array}$ & $\begin{array}{c}\text { Plaque forming cells } / 10^{6} \\
\text { mononuclear cells } \pm \mathrm{S} . \mathrm{E} .\end{array}$ \\
\hline$n$ & 12 \\
0 & $14681 \pm 3379$ \\
2.5 & $12490 \pm 3079^{1}$ \\
7.5 & $10905 \pm 3078^{1}$ \\
12.5 & $6763 \pm 1611^{2}$ \\
\hline
\end{tabular}

$$
\begin{aligned}
& { }^{1} P<0.05 \\
& { }^{2} P<0.01
\end{aligned}
$$

Table 3. Lymphocyte proliferative responses in 10 theophylline-treated prematures

\begin{tabular}{cc}
\hline Time & cpm \pm S.E. \\
\hline $0 \mathrm{~h}$ & $20370 \pm 7598$ \\
$24 \mathrm{~h}$ & $22237 \pm 6186$ \\
$72 \mathrm{~h}$ & $20355 \pm 4067$ \\
$1 \mathrm{wk}$ & $31599 \pm 6266$ \\
$3 \mathrm{wk}$ & $30120 \pm 5803$ \\
$5 \mathrm{wk}$ & $24628 \pm 2357^{1}$ \\
\hline
\end{tabular}

${ }^{1} P<0.02$

line was inversely proportional to the drug concentration. IgG and IgM production was significantly reduced at $12.5 \mu \mathrm{g} / \mathrm{ml}$ theophylline $(P<0.02)$ and $\operatorname{IgA}$, at $25.0 \mu \mathrm{g} / \mathrm{ml}(P<0.01) . \operatorname{IgM}$ fell from $1643 \mathrm{ng}$ at zero levels to $1093 \mathrm{ng}$ at levels of $12.5 \mu \mathrm{g} / \mathrm{ml}$, whereas IgG fell from $1054 \mathrm{ng}$ to $789 \mathrm{ng}$ with the same drug dosage. IgA production at zero levels was $782 \mathrm{ng}$ and fell to 476 ng at $25.0 \mu \mathrm{g} / \mathrm{ml}$ (Fig. 1). The IgG production at $25.0 \mu \mathrm{g} / \mathrm{ml}$ of theophylline was not significantly different, with a $P$ value of 0.052 , but again reached significance at $50.0 \mu \mathrm{g} / \mathrm{ml}$.

The adult lymphocyte plaque forming cells response was significantly reduced $(P<0.05)$ with theophylline at $2.5 \mu \mathrm{g} / \mathrm{ml}$. The mean number of plaques formed was decreased from the baseline level by $54 \%$ at a theophylline level of $12.5 \mu \mathrm{g} / \mathrm{ml}$ (Table 2), at which drug level the radioimmunoassay (RIA) first demonstrated a significant reduction.

Effects of in vivo theophylline on lymphocyte proliferation in premature infants. The lymphocyte proliferative response to $\mathrm{mi}$ togen stimulation in 10 theophylline-treated premature infants was followed. These infants were studied at 0,24 , and $72 \mathrm{~h}$ after the initial dose and thereafter weekly for 3-5 wk. Serum levels of theophylline were measured with each specimen and the mean level was $7.8 \pm 0.4 \mu \mathrm{g} / \mathrm{ml}$. The mean of the highest theophylline level in each infant was $11.8 \pm 0.9 \mu \mathrm{g} / \mathrm{ml}$. Two children initially had no response to mitogen but subsequently developed responses within the following $72 \mathrm{~h}$. One of these infants developed staphylococcus aureus sepsis during the course of therapy, which was associated with no change in his mitogen responses.

No decrease in lymphocyte proliferative responses to PWM stimulation was detected in any of these infants (Table 3). In contrast, there was a significant $(P<0.02)$ increase in proliferation after 3-5 wk.

Because all of the infants in the study received blood transfusions at some point in their course, the effect on lymphocyte proliferation of an initial blood transfusion was studied in three premature infants, who received antibiotics but were not on theophylline. They had a mean birth weight of $1270 \mathrm{~g}$ and a gestational age of $30 \mathrm{wk}$. Two of the infants received packed red blood cell transfusions and the third received a whole blood transfusion. The response to PWM in the transfused blood was also measured and was less than the response found in the infant both before and after his transfusion. No marked changes in lymphocyte proliferation were discovered in any of the three infants $24 \mathrm{hr}$ after receiving the transfusion (Table 4).

The variation in responses to PWM expressed as mean cpm was examined in nine cord blood samples obtained from normal term newborns. Six different dilutions with RPMI 1640 were made in 
Table 4. Effects of a blood transfusion on lymphocyte proliferation

\begin{tabular}{clccc}
\hline Infant & $\begin{array}{c}\text { Donor } \\
\text { blood }\end{array}$ & $\begin{array}{c}\text { Donor } \\
\text { blood } \\
\text { mean cpm }\end{array}$ & $\begin{array}{c}\text { Infant pretransfu- } \\
\text { sion mean cpm }\end{array}$ & $\begin{array}{c}\text { Infant posttrans- } \\
\text { fusion mean cpm }\end{array}$ \\
\hline 1 & PRBC $^{1}$ & 6550 & 24910 & 38149 \\
2 & WB $^{2}$ & 2919 & 16913 & 18043 \\
3 & PRBC $^{1}$ & 14457 & 15884 & 15297 \\
\hline
\end{tabular}

${ }^{1}$ PRBC, packed red blood cells

${ }^{2} \mathrm{WB}$, whole blood

Table 5. Mononuclear cells dilutional effects on lymphocyte proliferation

\begin{tabular}{cccc}
$\begin{array}{c}\text { Whole blood } \\
\text { dilution }\end{array}$ & $\begin{array}{c}\mathrm{cpm} \\
\text { mean } \pm \text { S.E. }\end{array}$ & $P$ value $^{\prime}$ & $\begin{array}{c}\text { Mononuclear cells } \times \\
10^{5} / \mathrm{ml} \\
\text { mean } \pm \text { S.E. }\end{array}$ \\
\hline $1: 9$ & $21414 \pm 2623$ & $<0.50$ & $5.7 \pm 0.6$ \\
$1: 11$ & $21755 \pm 3319$ & & $4.7 \pm 0.5$ \\
$1: 13$ & $22124 \pm 3011$ & $<0.50$ & $3.9 \pm 0.4$ \\
$1: 15$ & $22194 \pm 3614$ & $<0.50$ & $3.4 \pm 0.3$ \\
$1: 20$ & $20518 \pm 3552$ & $<0.30$ & $2.6 \pm 0.3$ \\
\hline
\end{tabular}

${ }^{1}$ Compared to the 1:11 dilution used in each experiment.

each cord sample. There were no significant differences in responses to PWM in those dilutions ranging from 1:9 to 1:20 (Table $5)$. These dilutions represented a range of $2.6-5.7 \times 10^{5}$ mononuclear cells $/ \mathrm{ml}$. There were technical difficulties at the $1: 5$ dilution resulting from quenching due to excess hemoglobin remaining in the harvested sample.

In spite of substantial changes in mononuclear cell numbers per well, there are nonsignificant variations in responses to PWM. This is probably indicative of the degree of recruitment of nonspecific cells to proliferate after a few mitogen-specific $T$ cells are stimulated, as indicated by Tse et al. (20).

\section{DISCUSSION}

The mechanism by which theophylline affects various biological systems has been postulated to be its inhibition of phosphodiesterase, and secondary elevation of intracellular c-AMP (14). Recently, there have been several reports regarding the effects of theophylline, as well as other agents which increase intracellular c-AMP levels, on in vitro and/or in vivo immune function.

In animal studies, theophylline has been shown to affect macrophage function (5), and $T$ and $B$ cell-mediated immunity (15). It inhibits phagocytosis (5), macrophage cytotoxic activity (17) and allograft rejection (13). Low doses of theophylline stimulate immunoglobulin formation, whereas high doses are inhibitory (3). Interestingly, early exposure of lymphocytes has been shown to be excitatory, whereas late exposure inhibits antibody production (4).

In humans, Gelfand et al. (8) have shown theophylline to augment $T$ suppressor cell activity, and Gupta et al. (9) have demonstrated a decrease in $\mathrm{T}$ cells in vivo with receptors for IgM $(\mathrm{T} \mu)$, generally considered to be helper cells. In contrast, Katz and Fauci (11) found an enhancement of B cell activation by a selective effect on the $\mathrm{T}$ cells, and postulated an inhibition of suppressor $\mathrm{T}$ cells. Furthermore, it has been shown to reduce T lymphocyte $\mathrm{E}$ rosette formation (12) and lymphocyte transformation (10). Human IgE-mediated skin tests are decreased by theophylline therapy (6). Also, Sherman et al. (18) have found increased immunoglobulin synthesis by normal human peripheral lymphocytes, however, the cells were only briefly exposed to theophylline. These results are consistent with animal studies showing induced stimulation of immune response by early, low doses of theophylline $(3,4)$. Finally, Bourne et al. (1) have shown that theophylline inhibits the candidal killing ability of human granulocytes. Thus, previous work has shown a wide range of effects by theophylline on both animals and humans.

We found significant decreases in lymphocyte proliferation in adults and term infants. Interestingly, we found slight but significant increases in the premature infants' responses to mitogen after a period of 3-5 wk, rather than a decrease. We consider this to be due most probably to maturational changes in the infants, possibly masking any depression caused by theophylline. It could also be due to the generally low theophylline levels generated in the infants. Another explanation might be that in vitro studies are not necessarily comparable to data obtained in vivo.

Interestingly, we also found a slight but insignificant increase in adult IgA and IgG production in human lymphocyte cultures with theophylline levels of $2.5 \mu \mathrm{g} / \mathrm{ml}$ by radioimmunoassay. This is consistent with the animal studies demonstrating stimulation by low dose theophylline exposure (3); however, at all other doses in the radioimmunoassay and in the plaque forming cells assay, theophylline inhibited immunoglobulin production.

Although we found no suppression of lymphocyte proliferation in premature infants during theophylline treatment, this does not exclude the possibility of changes in immuno-regulation, because changes in the suppressor/helper cell system may not be detected in assays measuring only lymphocyte proliferation. Further studies of the effects of theophylline on immunoregulatory function in neonates are needed.

\section{REFERENCES AND NOTES}

1. Bourne, H. R., Lehrer, R. I., Cline, M. J., and Melmon, K. L.: Cyclic 3', 5'adenosine monophosphate in the human leukocyte: synthesis, degradation, and effects on neutrophil candidacidal activity. J. Clin. Invest. 50: 920 (1971).

2. Boyum. A.: Separation of leukocytes from blood and bone marrow. Scand. J. Clin. Lab. Invest., 21 (Supplement): 97 (1968).

3. Braun. W. and Ishizuka. M.: Antibody formation: reduced responses after administration of excessive amounts of nonspecific stimulators. Proc. Natl. Acad. Sci. U.S.A., 68: 1114 (1971).

4. Burchiel, S. W. and Melmon, K. L.: Augmentation of the in vitro humoral immune response by pharmacologic agents. I: An explanation for the differential enhancement of humoral immunity via agents that elevate cAMP. Immunopharmacol., l: 137 (1979).

5. Cox, J. P. and Karnovsky, M. L.: The depression of phagocytosis by exogenous cyclic nucleotides, prostaglandins, and theophylline. J. Cell. Biol., 59: 480 (1973).

6. Fine, S. R., Fogarty, M.. Goel, Z., and Grieco, M. H.: Correlation of serum theophylline levels with inhibition of allergen and histamine-induced skin tests. Int. Archs. Allergy Appl. Immunol., 61: 241 (1980).

7. Fauci, A. S., Whalen, G., and Burch, C.: Activation of human B-lymphocytes: XVI. Cellular requirements, interactions, and immunoregulation of pokeweed mitogen-induced total immunoglobulin producing plaque-forming cells in peripheral blood. Cell. Immunol., 54: 230 (1980).

8. Gelfand, E. W., Dosch, H. M., Hastings, D., and Shore, A.: Lithium: a modulator of cyclic AMP-dependent events in lymphocytes. Science, 203: 365 (1979).

9. Gupta, S., Fikrig, S., and Good, R. A.: Subpopulations of human T lymphocytes: XIII $\mathrm{T}$ cell subpopulations ( $\mathrm{T}_{\gamma}$ and $\mathrm{T}_{\mu}$ ) in children with bronchial asthma. Int. Archs. Allergy Appl. Immunology, 61: 293 (1980).

10. Hirschhorn, R., Grossman, J., and Weissmann, G.: Effect of cyclic 3', 5'-adenosine monophosphate and theophylline in lymphocyte transformation. Proc. Soc. Exper. Biol. Med., 133: 1361 (1970).

11. Katz, P., and Fauci, A. S.: Activation of human B lymphocytes: VII. The regulatory effect of cyclic monophosphate on human B cell activation. J. Allergy Clin. Immunol., 61: 334 (1978).

12. Limatibul, S., Shore, A., Dosch. H. M., and Gelfand, E. W.: Theophylline modulation of E-rosette formation: an indicator of $\mathrm{T}$-cell maturation. Clin. Exp. Immunol.. 33: 503 (1978).

13. Ljungstrom, I. and Holmgren, J.: In vivo suppression of allograft rejection by cyclic AMP increasing agents. Int. Archs. Allergy Appl. Immunol., 58: 99 (1979).

14. Lucey, J. F.: The xanthine treatment of apnea of prematurity. Pediatrics, 55: 584 (1975).

15. Plaut, M.: The role of cyclic AMP in modulating cytotoxic T lymphocytes: I. In vivo-generated cytotoxic lymphocytes, but not in vitro-generated cytotoxic lymphocytes, are inhibited by cyclic AMP-active agents. J. Immunol., I23: 692 (1979).

16. Ruuskanen, O., Pittard, W. B., Sorensen, R. U., and Polmar, S. H.: Lymphocyte stimulation assay utilizing heel skin puncture blood samples. J. Clin. Lab. Immunol., 4: 111 (1980).

17. Schultz, R. M., Chirigos, M. A., Stoychkov, J. N., and Pavlidis, N. A.: Factors affecting macrophage cytotoxic activity with particular emphasis on corticosteroids and acute stress. J. Reticuloendothel. Soc., 26: 83 (1979).

18. Sherman, N. A., Smith, M. S., and Middleton, E.: Effect of adrenergic com- 
pounds, aminophylline and hydrocortisone, on in vitro immunoglobulin synthesis by normal human peripheral lymphocytes. J. Allergy Clin. Immunol., 52: 13 (1973)

19. Simmons, F. E., Friesen, F. R., and Simons, K. J.: Theophylline toxicity in term infants. Am. J. Dis. Child., 134: 39 (1980).

20. Tse, H. Y., Schwartz, R. H., and Paul, W. E.: Cell-cell interactions in the T cell proliferative response: I. Analysis of the cell types involved and evidence for nonspecific T cell recruitment. J. Immunol., I25: 491 (1980).

21. Uauy, R., Shapiro, D., Smith, B., and Warshaw, J. B.: Treatment of severe apnea in prematures with orally administered theophylline. Pediatrics, 55: 595 (1975).
22. Waldmann, T. A., Polmar, S. H., Balestra, S. T., Jost, M. C., Bruce, R. M., and Terry, W. D.: Immunoglobulin E in immunologic deficiency disease: II Serum IgE concentration of patients with acquired hypogammaglobulinemia, thymoma, and hypogammaglobulinemia myotonic dystrophy, intestinal lymphangiectasia and Wiscott Aldrich Syndrome. J. Immunol., 109: 304 (1972).

23. Requests for reprints should be addressed to: Dr. J. E. Baley, Department of Pediatrics, Rainbow Babies and Children's Hospital, 2101 Adelbert Rd., Cleveland, $\mathrm{OH} 44106$.

24. Received for publication November 5, 1980.

25. Accepted for publication February 2, 1982. 